\title{
Environmental interventions to reduce fear of crime: systematic review of effectiveness
}

\author{
Theo Lorenc ${ }^{1 *}$, Mark Petticrew ${ }^{1}$, Margaret Whitehead ${ }^{2}$, David Neary ${ }^{2}$, Stephen Clayton ${ }^{2}$, Kath Wright ${ }^{3}$, \\ Hilary Thomson ${ }^{4}$, Steven Cummins ${ }^{1,5}$, Amanda Sowden ${ }^{3}$ and Adrian Renton ${ }^{6}$
}

\begin{abstract}
Background: Fear of crime is associated with negative health and wellbeing outcomes, and may mediate some impacts of the built environment on public health. A range of environmental interventions have been hypothesized to reduce the fear of crime.

Methods: This review aimed to synthesize the literature on the effectiveness of interventions in the built environment to reduce the fear of crime. Systematic review methodology, following Preferred Reporting Items for Systematic Reviews and Meta-Analyses (PRISMA) guidance, was used. Studies of environmental interventions which reported a fear of crime outcome and used any prospective evaluation design (randomized controlled trial (RCT), trial or uncontrolled before-and-after study) were included. Eighteen databases were searched. The Hamilton tool was used to assess quality. A narrative synthesis of findings was undertaken.
\end{abstract}

Results: A total of 47 studies were included, 22 controlled and 25 uncontrolled, with total sample sizes ranging from $n=52$ to approximately $n=23,000$. Thirty-six studies were conducted in the UK, ten studies in the USA and one study in the Netherlands. The quality of the evidence overall is low. There are some indications that home security improvements and non-crime-related environmental improvements may be effective for some fear of crime outcomes. There is little evidence that the following reduce fear of crime: street lighting improvements, closed-circuit television (CCTV), multi-component environmental crime prevention programs or regeneration programs.

Conclusions: There is some evidence for the effectiveness of specific environmental interventions in reducing some indicators of fear of crime, but more attention to the context and possible confounders is needed in future evaluations of complex social interventions such as these.

Keywords: Fear of crime, Systematic review, Built environment, Intervention effectiveness

\section{Background}

Fear of crime is known to be associated with a number of negative mental and physical health outcomes [1]. The fear of crime may cause mental health problems directly, and it may also reduce outdoor physical activity and social interaction [1]. Conversely, mental health problems may increase fear of crime, potentially leading to a feedback effect which can exacerbate both $[2,3]$. Crime itself also appears to have negative impacts on health: rates of violent crime at neighborhood level have

\footnotetext{
* Correspondence: theo.lorenc@lshtm.ac.uk

'Department of Social and Environmental Health Research, London School of Hygiene \& Tropical Medicine, 5-17 Tavistock Place, London WC1H 9SH, UK Full list of author information is available at the end of the article
}

been found to be associated with a range of health behaviors and outcomes $[1,4]$. This suggests that interventions to reduce crime or the fear of crime may potentially be a way to improve health and wellbeing outcomes, particularly mental health, at a community level.

Furthermore, both crime and the fear of crime may be influenced by factors in the built environment. The impact of built environment factors on crime rates have been a focus of Crime Prevention Through Environmental Design (CPTED) theory, which emphasizes factors such as natural surveillance and access control as environmental determinants of crime [5,6]. Several built environment interventions are known to be effective in reducing crime, including street lighting [7] and

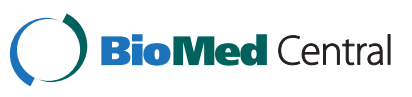


environmental programs for robbery prevention in retail settings [8]. Fear of crime is also associated with environmental factors such as litter, graffiti and patterns of land use (for example residential versus non-residential) [1]. Combining these pathways, it appears that crime and the fear of crime may mediate the effects of the physical environment on public health [9].

Thus, interventions involving changes to the physical environment may be a promising way to address fear of crime, and the broader health and wellbeing impacts of crime. The built environment has been identified as a key locus of intervention to reduce health inequalities by addressing 'upstream' social determinants of health outcomes [10]. That is, environmental changes can help to address the macro-level determinants of health behaviors, not only in disadvantaged areas, but also across the population as a whole. However, this point has received less attention in the field of crime prevention [11]. (Indeed, in criminology a focus on physical environmental factors has arguably been associated with the opposite shift, away from the upstream determinants of crime and towards individual-level situational determinants.) Therefore, focusing on environmental interventions also helps to bridge the hitherto largely distinct fields of public health and crime prevention. The aim of this review was to synthesize the evidence of the effectiveness of environmental interventions on fear of crime.

\section{Methods}

The protocol for the review is available on the National Institute for Health Research (NIHR) Public Health Research (PHR) Programme website: http://www.phr.nihr. ac.uk/funded_projects/09_3000_14.asp. The review was conducted according to Preferred Reporting Items for Systematic Reviews and Meta-Analyses (PRISMA) guidance (www.prisma-statement.org/).

\section{Search strategy and inclusion criteria}

The following databases were searched: Applied Social Sciences Index and Abstracts (ASSIA), Cumulative Index to Nursing and Allied Health Literature (CINAHL), Conference Proceedings Citation Index, Criminal Justice Abstracts, Dissertation Abstracts, EconLit, Embase, Education Resources Information Center (ERIC), Health Management Information Consortium (HMIC), Inside Conferences, MEDLINE, National Criminal Justice Reference Service (NCJRS), PsycINFO, Science Citation Index, Social Policy and Practice, Social Sciences Citation Index, Sociological Abstracts, and Urban Studies Abstracts. Searches were conducted between November 2010 and January 2011. All sources were searched from inception to the most current records, without date or language restrictions. Terms used in the search included terms for fear of crime, crime, antisocial behaviour, and factors and interventions in the built environment. The full MEDLINE search strategy can be found in web-only Additional file 1 (searches for other databases used a modified form of the MEDLINE search strategy). In addition, we also searched Google and Google Scholar; scanned the reference lists of included studies; searched websites of various government bodies, research groups and other relevant organizations; and consulted the review Advisory Group.

Inclusion criteria were as follows: 1 . intervention involving a substantial change to the built environment; 2 . study reporting data on any fear of crime-related outcome, including perceptions or feelings of safety, estimations of one's own risk, worry about specific crimes or crime in general, or any other crime-related affective outcome or crime-related avoidance behaviors; 3 . prospective intervention evaluation of any design, including randomized controlled trials (RCTs), trials and uncontrolled before-and-after studies (with non-randomized studies required to report outcome data both before and after the intervention); and 4. study conducted in a country which is a current member of the Organization for Economic Co-operation and Development (OECD).

An initial sample of $10 \%$ of abstracts was screened by two reviewers independently and differences resolved by discussion. The remainder of the abstracts was screened by one reviewer alone. At full-text screening stage, $50 \%$ of the included studies were screened by two reviewers independently.

\section{Data extraction and quality assessment}

Data were extracted from the studies using a standardized form, which included information on the context and setting of the study, population, methodology and findings. Data extraction and quality assessment for all studies were carried out by a single reviewer and a sample was double-checked in detail by a second reviewer.

Quality assessment for the effectiveness review was carried out using a version of the Hamilton tool [12], as modified by Thomson et al. [13]. This tool includes six domains: selection bias, study design, confounders, blinding, data collection, and withdrawals and dropouts. These domains were used to produce an overall quality rating: A (high quality), $\mathrm{B}$ (medium quality) or $\mathrm{C}$ (low quality), using the algorithm set out in web-only Additional file 2.

\section{Data synthesis}

Data were synthesized narratively according to intervention type. Studies were not excluded based on their quality ratings, but more emphasis was placed on higher quality studies when reporting and interpreting the results. Meta-analysis was not carried out, owing to the 
substantive and methodological heterogeneity of the studies. Since many studies measure several distinct fear of crime outcomes, an indicative quantitative summary measure was developed. We standardized all measures to a 0 to 100 scale, inverted where necessary so that substantively positive findings (for example reduced fear or increased perceived safety) were expressed in the same direction (as a positive number). We then calculated a median effect size across all relevant outcomes for each study, expressing relative changes for studies using controlled designs (the difference of baseline and post-test differences between intervention and comparison group) and within-group changes for studies using uncontrolled designs (the difference between pre- and post-intervention). We also extracted data on population subgroups (age, gender, ethnicity and socioeconomic status) and conducted a separate narrative synthesis of these data to identify any equity implications.

\section{Results}

\section{Flow of literature through the review}

Figure 1 shows the flow of literature through the review. Forty-seven studies were included in the review.

\section{Intervention content and quality assessment}

Table 1 shows the quality ratings assigned to the studies, the study designs used and a brief description of the content of the intervention.

Sample size indicates sample at baseline in intervention and control groups, or total for non-comparative studies; 'total' shown for comparative studies where only total sample size is reported. Follow-up shows time from completion of intervention to latest outcome measurement for which data are available, except studies marked 'as which indicates follow-up measured from the start of the intervention. Quality ratings: A, high quality; B, medium quality; $\mathrm{C}$, low quality. $\mathrm{CBA}(\mathrm{S})$, controlled before-and-after study with same participants before and after; $\mathrm{CBA}(\mathrm{D}+)$, controlled before-and-after study with different participants before and after, and with no evidence of change in population; $\mathrm{CBA}(\mathrm{D}-)$, controlled before-and -after study with different participants before and after, and with some evidence of change in population; CCTV, closed-circuit television; CPTED, Crime Prevention Through Environmental Design; I/C, intervention/control group; NR, not reported; RCT, randomized controlled trial; UBA(D), uncontrolled (single-group) before-and -after study with different participants before and after; UBA(S), uncontrolled (single-group) before-and-after study with same participants before and after.

As shown in Table 1, seven categories of interventions were distinguished: 1 . Home security improvements (some of these interventions also included other components); 2. installation or improvement of street lighting; 3. installation of closed-circuit television (CCTV) systems; 4. multi-component interventions for crime prevention (most focused on public areas); 5. housing improvement and relocation; 6. area-based regeneration initiatives (involving a broad range of components); and 7. small-scale environmental improvements in public

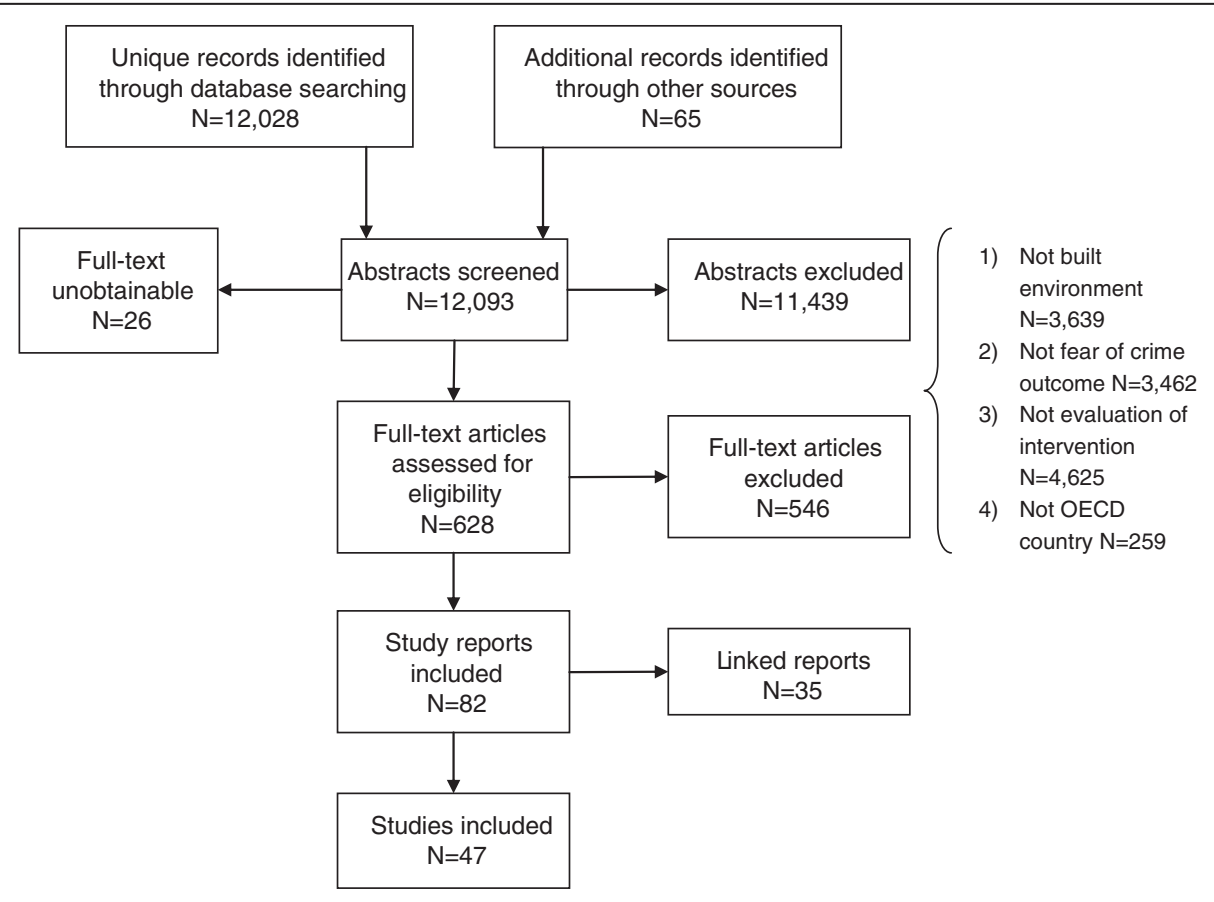

Figure 1 Flow of literature through the review. 
Table 1 Characteristics and quality ratings of the studies in the effectiveness review $(n=47)$

\begin{tabular}{|c|c|c|c|c|c|c|}
\hline $\begin{array}{l}\text { First author } \\
\text { [reference(s)] }\end{array}$ & Design & $\begin{array}{l}\text { Sample } \\
\text { size (I/C) }\end{array}$ & Follow-up & $\begin{array}{l}\text { Quality } \\
\text { rating }\end{array}$ & Location & Intervention content \\
\hline \multicolumn{7}{|c|}{ Category 1. Home security improvements } \\
\hline Allatt $[14,15]$ & $\mathrm{CBA}(\mathrm{S})$ & $338 / 322$ & 1 year & A & $\begin{array}{l}\text { Newcastle and } \\
\text { Gateshead, UK }\end{array}$ & $\begin{array}{l}\text { Improvement of residential security } \\
\text { on deprived housing estates }\end{array}$ \\
\hline Brownsell [16] & $\mathrm{CBA}(\mathrm{S})$ & $24 / 28$ & 5 years & A & UK, location NR & $\begin{array}{l}\text { Telecare package in sheltered housing } \\
\text { for older people }\end{array}$ \\
\hline Halpern [17] & UBA(S) & 55 & 3 years $^{a}$ & C & UK, location NR & $\begin{array}{l}\text { Comprehensive renovation program on } \\
\text { housing estate, with emphasis on security }\end{array}$ \\
\hline Matthews [18] & UBA(D) & 636 & 1 year $^{a}$ & C & Leicester, UK & $\begin{array}{l}\text { Multi-component crime reduction strategy, } \\
\text { including residential security and social } \\
\text { components }\end{array}$ \\
\hline Matthews [19] & UBA(D) & 907 & 1 year $^{a}$ & C & Leicester, UK & Similar to Matthews [18] \\
\hline \multicolumn{7}{|c|}{ Category 2. Installation or improvement of street lighting } \\
\hline Atkins [20] & $\mathrm{CBA}(\mathrm{S})$ & $248 / 131$ & 2 months & A & $\begin{array}{l}\text { Wandsworth, London, } \\
\text { UK }\end{array}$ & Improvement of street lighting \\
\hline Bainbridge [21] & UBA(S) & 468 & 1 year & $\mathrm{B}$ & Birmingham, UK & Improvement of street lighting \\
\hline Barr [22] & UBA(S) & 229 & 2 months & C & Manchester, UK & Improvement of street lighting \\
\hline Burden [23] & UBA(D) & NR & NR & C & Leeds, UK & Improvement of street lighting \\
\hline Davidson [24] & UBA(S) & 251 & 6 weeks & C & Hull, UK & Improvement of street lighting \\
\hline Herbert $[25,26]$ & UBA(S) & 154 & 2 months & C & Cardiff, UK & Improvement of street lighting \\
\hline Knight [27] & UBA(S) & 125 & 3 weeks & C & St Helens, UK & $\begin{array}{l}\text { Change of street lighting from yellow } \\
\text { to white lights }\end{array}$ \\
\hline Painter $[28,29]$ & UBA(D) & 207 & 6 weeks & C & North London, UK & Improvement of street lighting \\
\hline Painter $[29,30]$ & UBA(D) & 143 & 6 weeks & C & East London, UK & Improvement of street lighting \\
\hline Painter $[29,31]$ & UBA(S) & 263 & 13 months & B & West London, UK & Improvement of street lighting \\
\hline Painter [32] & $\mathrm{CBA}(\mathrm{S})$ & $431 / 443$ & 1 year & $A$ & Dudley, UK & Improvement of street lighting \\
\hline Painter [33] & $\mathrm{CBA}(\mathrm{S})$ & $317 / 88$ & 11 months & A & Stoke-on-Trent, UK & Improvement of street lighting \\
\hline Painter [34] & $\mathrm{CBA}(\mathrm{S})$ & $140 / 167$ & 1 year & A & Dudley, UK & Same intervention as Painter [32] \\
\hline Payne [35] & UBA(S) & 228 & $<1$ year & C & Rugby, UK & Improvement of street lighting \\
\hline Vamplew [36] & UBA(D) & 820 & $<1$ month & C & Middlesbrough, UK & Improvement of street lighting \\
\hline Vrij [37] & UBA(D) & 160 & 1 week & C & $\begin{array}{l}\text { Enkhuizen, the } \\
\text { Netherlands }\end{array}$ & $\begin{array}{l}\text { Brighter bulbs and installation of } \\
\text { one extra lamppost }\end{array}$ \\
\hline \multicolumn{7}{|c|}{ Category 3. Installation of closed-circuit television (CCTV) systems } \\
\hline Brown [38] & UBA(D) & 699 & 1 year & C & Birmingham, UK & $\begin{array}{l}\text { Installation of } 12 \text { CCTV cameras } \\
\text { in city centre }\end{array}$ \\
\hline Ditton [39] & $\mathrm{CBA}(\mathrm{D}+)$ & 1,018 total & 15 months & C & Glasgow, UK & $\begin{array}{l}\text { Installation of } 32 \text { CCTV cameras } \\
\text { in city centre }\end{array}$ \\
\hline Gill $[40,41]$ & $\mathrm{CBA}(\mathrm{D}-)$ & $4,427 / 2,099$ & 1 year & C & $\begin{array}{l}\text { Several locations, } \\
\text { England }\end{array}$ & $\begin{array}{l}\text { Installation of nine different CCTV systems, } \\
\text { four in town/city centers, five in } \\
\text { residential areas }\end{array}$ \\
\hline Musheno [42] & $\mathrm{CBA}(\mathrm{D}+)$ & $32 / 29$ & 3 months & C & $\begin{array}{l}\text { New York City, NY, } \\
\text { USA }\end{array}$ & $\begin{array}{l}\text { CCTV in public housing project } \\
\text { with transmission } \\
\text { to residents' television sets }\end{array}$ \\
\hline Squires [43] & UBA(D) & 750 & 8 months & C & East London, UK & Installation of CCTV in town centre \\
\hline Squires [44] & UBA(D) & 243 & 1 year & C & Brighton, UK & $\begin{array}{l}\text { Installation of } 10 \text { CCTV cameras in } \\
\text { housing estate }\end{array}$ \\
\hline \multicolumn{7}{|c|}{ Category 4. Multi-component interventions for crime prevention } \\
\hline $\begin{array}{l}\text { Arthur Young \& } \\
\text { Company }[45,46]\end{array}$ & $\mathrm{CBA}(\mathrm{S})$ & $920 / 150$ & 2 years $^{a}$ & A & Chicago, IL, USA & $\begin{array}{l}\text { Multi-component intervention in a housing } \\
\text { estate (locks, security personnel, entry systems, } \\
\text { fencing, various social components) }\end{array}$ \\
\hline Baker [47] & $\mathrm{CBA}(\mathrm{D}-)$ & $124 / 337$ & 6 months & C & Pennsylvania, PA, USA & $\begin{array}{l}\text { Multi-component intervention in a park } \\
\text { (CCTV, fencing, lighting, locks, signage, } \\
\text { cleaning, community policing, } \\
\text { Neighborhood Watch) }\end{array}$ \\
\hline
\end{tabular}


Table 1 Characteristics and quality ratings of the studies in the effectiveness review $(n=47)$ (Continued)

\begin{tabular}{|c|c|c|c|c|c|c|}
\hline Donnelly $[48,49]$ & UBA(D) & 191 & 5 years & C & Dayton, $\mathrm{OH}, \mathrm{USA}$ & $\begin{array}{l}\text { Multi-component community-based program } \\
\text { (road closures, various social components, } \\
\text { community-oriented policing) }\end{array}$ \\
\hline Felson [50] & UBA(D) & 3,581 & 3 years & C & $\begin{array}{l}\text { New York City, NY, } \\
\text { USA }\end{array}$ & $\begin{array}{l}\text { Extensive physical redesign of bus station } \\
\text { using CPTED principles (redesign, renovation, } \\
\text { cleaning, lighting, information, social and } \\
\text { policing interventions for homeless people) }\end{array}$ \\
\hline Fowler [51-54] & $\mathrm{CBA}(\mathrm{D}+)$ & $93 / 798$ & 3 years & C & Hartford, CT, USA & $\begin{array}{l}\text { Multi-component community-based program } \\
\text { (road closures, landscaping, community- } \\
\text { oriented policing, resident organizations) }\end{array}$ \\
\hline Kaplan [55] & CBA(D-) & 2,772 total & 6 months & C & $\begin{array}{l}\text { Broward County, FL, } \\
\text { USA }\end{array}$ & $\begin{array}{l}\text { Extensive renovation work in schools using } \\
\text { CPTED principles (renovation, reconstruction, } \\
\text { fencing, alarms) }\end{array}$ \\
\hline Kaplan [56-58] & $\mathrm{UBA}(\mathrm{D})$ & 311 & 3 years $^{a}$ & C & Portland, OR, USA & $\begin{array}{l}\text { Multi-component community-based intervention } \\
\text { with emphasis on commercial premises } \\
\text { (security advice, lighting, traffic calming, } \\
\text { landscaping, cleaning, bus shelters, business } \\
\text { organization, social programs) }\end{array}$ \\
\hline Mazerolle $[59,60]$ & $\mathrm{RCT}$ & $\begin{array}{l}\text { Approx. } \\
\text { 199/199 }\end{array}$ & 3 months & B & Oakland, CA, USA & $\begin{array}{l}\text { Police-led intervention with focus on reducing } \\
\text { disorder in the physical environment by } \\
\text { enforcing building/housing codes }\end{array}$ \\
\hline Webb [61] & $\mathrm{CBA}(\mathrm{D}+)$ & $\begin{array}{l}\text { Approx. } \\
560 / 560\end{array}$ & Unclear & C & London, UK & $\begin{array}{l}\text { Multi-component crime prevention project } \\
\text { on the London Underground (CCTV, } \\
\text { passenger alarms, manned kiosks, mirrors, } \\
\text { lighting, policing patrols) }\end{array}$ \\
\hline \multicolumn{7}{|c|}{ Category 5. Housing improvement and relocation } \\
\hline Barnes [62] & $\mathrm{CBA}(\mathrm{S})$ & $199 / 85$ & 6 months & C & West London, UK & $\begin{array}{l}\text { Refurbishing housing association housing } \\
\text { and relocating tenants to new, } \\
\text { improved housing }\end{array}$ \\
\hline Blackman $[63,64]$ & UBA(S) & 415 & 5 years $^{a}$ & C & Newcastle, UK & $\begin{array}{l}\text { Housing renewal program (environmental } \\
\text { improvements, refurbishment, demolition, } \\
\text { security, road safety improvements) }\end{array}$ \\
\hline Critchley [65] & $\mathrm{CBA}(\mathrm{S})$ & $200 / 207$ & 1 year & A & Liverpool, UK & $\begin{array}{l}\text { Housing redevelopment with main focus on } \\
\text { energy efficiency, security improvements } \\
\text { (entry systems, CCTV, lighting) }\end{array}$ \\
\hline Foster [66] & CBA(D-) & $820 / 862$ & 3 years $^{a}$ & C & $\begin{array}{l}\text { East London and Hull, } \\
\text { UK }\end{array}$ & $\begin{array}{l}\text { Tenant management program including } \\
\text { environmental improvements (security, } \\
\text { maintenance, landscaping, entry systems) }\end{array}$ \\
\hline GoWell $[67,68]$ & $\mathrm{CBA}(\mathrm{D}+)$ & 6,008 total & 2 years $^{a}$ & C & Glasgow, UK & $\begin{array}{l}\text { Several types of regeneration and housing } \\
\text { program, ranging from extensive rebuilding } \\
\text { to minor renovation works }\end{array}$ \\
\hline Nair [69] & UBA(S) & 69 & 3 months & C & Glasgow, UK & $\begin{array}{l}\text { Re-lighting, landscaping, housing renovation, } \\
\text { including security improvements }\end{array}$ \\
\hline Petticrew $[70,71]$ & $\mathrm{CBA}(\mathrm{S})$ & $334 / 389$ & 2 years & A & $\begin{array}{l}\text { Several locations, } \\
\text { Scotland }\end{array}$ & $\begin{array}{l}\text { Relocation of social housing tenants to } \\
\text { new housing }\end{array}$ \\
\hline \multicolumn{7}{|c|}{ Category 6. Area-based regeneration initiatives } \\
\hline Beatty [72-74] & $\mathrm{CBA}(\mathrm{S})$ & $\begin{array}{l}19,633 / \\
4,000\end{array}$ & 6 years $^{a}$ & A & $\begin{array}{l}\text { Several locations, } \\
\text { England }\end{array}$ & $\begin{array}{l}\text { Broad multi-component regeneration } \\
\text { program, New Deal for Communities }\end{array}$ \\
\hline Rhodes [75] & UBA(S) & 3,459 & 5 years $^{a}$ & C & $\begin{array}{l}\text { Several locations, } \\
\text { England }\end{array}$ & $\begin{array}{l}\text { Broad multi-component regeneration } \\
\text { program, Single Regeneration Budget }\end{array}$ \\
\hline \multicolumn{7}{|c|}{ Category 7. Small-scale environmental improvements in public areas } \\
\hline Cohen [76] & $\mathrm{CBA}(\mathrm{D}+)$ & 1,535 total & $\begin{array}{l}3 \text { to } 14 \\
\text { months }\end{array}$ & $\mathrm{C}$ & $\begin{array}{l}\text { South California, CA, } \\
\text { USA }\end{array}$ & Improvements to public parks \\
\hline Palmer [77] & $\mathrm{UBA}(\mathrm{D})$ & 290 & Unclear & $\mathrm{C}$ & Durham, UK & $\begin{array}{l}\text { Bus station repainted and graffiti } \\
\text { removed by offenders serving } \\
\text { Community Service Orders }\end{array}$ \\
\hline
\end{tabular}


areas. Of these, categories 1 to 4 include interventions whose main aim was to reduce or prevent crime and/or the fear of crime, while categories 5 to 7 include interventions which did not have such an aim, but which measured the effect of the intervention on fear-of-crimerelated outcomes.

Study quality overall was generally low: 10 studies were graded as high quality (A), three as medium quality (B) and 34 as low quality (C). The generally low ratings primarily reflect two aspects of the evidence base: the large number of uncontrolled studies, or studies using an inadequately matched control group; and the incomplete reporting of methods, particularly relating to sampling and recruitment.

The findings are summarized for each intervention category. Within each category the findings from higherquality, controlled studies are presented first, followed by those from uncontrolled studies.

\section{Home security improvements}

Five studies were identified in this category, all from the UK. The interventions covered a range of approaches. One study was narrowly focused on providing security improvements to homes [14], while the other studies combined home security with a range of other security and non-security improvements. In one study, security improvements were undertaken within the context of a telecare intervention for older people in sheltered housing [16]. In another study, the security improvements formed part of a broader program of work, which also included broader improvements to homes as well as to the surrounding area (including improved lighting, landscaping and alley gating) [17].

Two controlled studies found reductions in fear of crime as a result of home security improvements (15\% [14] and 16\% [16]). One uncontrolled study reported similar reductions (18\% [17]), while two other uncontrolled studies found no change in fear of crime outcomes $(0.1 \%$ across both studies $[18,19])$.

Overall, the evidence indicates that home security improvements in a range of different contexts may be promising for reducing fear of crime.

\section{Installation or improvement of street lighting}

Sixteen studies, four controlled and twelve uncontrolled, investigated the effects of street lighting improvements on fear of crime. Fifteen studies were conducted in the UK and one in the Netherlands.

Fourteen studies looked at the effect of improving lighting at an area level on fear of crime in general. Four of these studies used controlled designs [20,32-34]. Of these, two found that the intervention did not reduce fear $(-1.5 \%$ for one study [33]; effect sizes were not clearly reported in the other [20]). One study found mixed results depending on the exact fear variable used, with significant improvements in two of five analyses (aggregate effect size 2.7\% [32]). The fourth study found a significant improvement in fear in a sample of young people (9.8\% [34]).

Ten further studies used uncontrolled designs to investigate similar interventions. Most of these studies found some improvement, although significance was often not reported. Seven studies showed a trend towards reduced fear (5.6\% [21], 6\% [25], 8\% [23], 8\% [24], $17 \%$ [30], 22\% [28] and 35\% [31]), and three studies showed no change or a trend towards increased fear $(0 \%$ [36], $-1 \%$ [22] and $-6 \%$ [35]).

Finally, two studies investigated smaller-scale changes, both using uncontrolled designs. One study investigated a change from conventional yellow sodium lighting to a new bulb type with a whiter light in North West England [27], and the other study investigated an increase in brightness, carried out in Enkhuizen, the Netherlands [37]. Both studies found significant reductions in fear of crime (19.7\% [27] and 15.1\% [37]).

Overall, the evidence regarding lighting is rather mixed. While the uncontrolled studies showed reductions in fear, these were generally not replicated in more rigorous studies, although some of the latter studies did show some positive effects.

\section{Installation of closed-circuit television (CCTV) systems}

Six studies investigating the effect of CCTV on fear of crime were identified, five studies from the UK and one study from the USA. Three controlled studies were identified. One of these studies was incompletely reported and did not appear to show any substantial change in fear levels [39]. The second controlled study, carried out in New York City, NY, USA, investigated the effect of the installation of CCTV in a public housing project with transmission to residents' television sets. It showed very mixed findings, with improvements in some fear outcomes and adverse changes in others (median 9.8\% [42]). The third and largest study concerned the effects of installations of CCTV in four town centers and five residential areas in England. It found some within-group reductions in fear (median within-group effect, 5\%), but little evidence of reduced fear when the control group was taken into account: out of sixteen analyses reported, only six showed positive comparative trends in fear outcomes (of which two were statistically significant) [40].

Three uncontrolled studies in England evaluated the impact of CCTV. Two studies showed slight positive trends (2\% [38] and 2.5\% [43]), and one study showed a negative trend ( $-7.5 \%$ [44]). Statistical significance was not measured in any of these studies. 
Overall, the evidence tends to show that CCTV is not effective in reducing fear of crime, although the quality of the evidence is limited.

\section{Multi-component interventions for crime prevention}

Nine studies investigated large-scale programs of environmental change to address crime or the fear of crime. Eight studies were based in various cities in the USA and one study was based in London, UK. Intervention components often included security improvements, lighting improvements and installation of CCTV, as well as more general environmental improvements such as landscaping or graffiti removal. In addition, many included non-built-environment components such as changes to policing practice (for example communityoriented policing) and/or social programs (for example drug treatment, employment initiatives). A range of settings were investigated, including residential and business areas, parks, schools and public transport stations.

Three controlled studies reported trends towards reductions in fear of crime $[45,51,61]$. Two of these studies investigated broad environmental crime reduction programs in residential areas in Chicago, IL, USA (6\% [45]), and Hartford, CT, USA (4\% [51]), which in one case was reported to reach significance, although the analysis is non-standard [51]. The third study focused on public transport stations in London and showed a positive trend in fear, although significance was not reported (7.5\% [61]).

However, two further controlled studies showed small and non-significant adverse trends towards increased fear: one study of a police-led intervention in Oakland, CA, USA, to address environmental problems at crime 'hot spots' (change scores not reported [59]), and the other study of a security program in schools in Broward County, FL, USA (-3.8\% [55]).

Two uncontrolled studies also showed reductions in fear of crime: one study of a police-led intervention in a crime 'hot spot' in a park in Pennsylvania, PA, USA $(29.8 \%[47])^{\mathrm{a}}$, and the other study in a public transport setting in New York City (21\% [50]), although significance was not reported. One further uncontrolled study of an intervention focusing on road closures in Dayton, $\mathrm{OH}$, USA, showed a non-significant trend toward reduced fear (6\% [48]). A fourth uncontrolled study showed mixed results, although with a median positive trend $(5 \%[56])$.

Overall, the findings on multi-component environmental crime reduction programs are mixed and do not constitute strong evidence of effectiveness in reducing fear.

\section{Housing improvement and relocation}

Seven studies, all carried out in UK cities, examined the effects of housing improvement on fear of crime outcomes. Three studies included renovation of existing housing $[63,66,69]$, one study focused on the provision of new housing and relocation of residents [70], and three studies included elements of both $[62,65,67]$.

Three controlled studies all showed small and nonsignificant improvements in fear of crime $(2.5 \%$ in Liverpool [65] and 7\% in London [62]; change scores are not reported for the third study, carried out in Hull and London [66]). Four uncontrolled studies showed varying results, with two studies showing significant reductions in fear of crime $\left(9.1 \%[70]^{\mathrm{b}}\right.$ and $16.1 \%$ [63]), one study showing no change (1.5\% [69]), and one study showing significant adverse effects in fear (-19\% [67]).

The findings on housing are very mixed. The variation in findings does not seem to depend on whether studies involved substantial relocation or not (as might be hypothesized, since relocation would disrupt social networks, thus potentially increasing fear of crime). However, there are some positive findings from reasonably robust studies.

\section{Area-based regeneration initiatives}

There were two studies in this category, involving large-scale nationwide urban regeneration programs conducted in the UK. Both the Single Regeneration Budget (SRB) [75] and the New Deal for Communities (NDC) [72] included a wide range of component initiatives (for example housing, environmental improvement, employment and economic development initiatives, and crime prevention). In both studies there was no clear trend in fear outcomes. The SRB evaluation showed a $2 \%$ within-group improvement [75]. The NDC evaluation showed substantial improvements in the intervention group over the timeframe of the evaluation (median within-group change, $13.5 \%$ ), but similar improvements were also found in the matched comparison group, so may not be attributable to the intervention (median comparative change, $-2.5 \%)$ [72].

\section{Small-scale environmental improvements in public areas}

One controlled study from the USA and one uncontrolled study from the UK looked at small-scale environmental improvements which were not primarily aimed at reducing crime. In the USA study, new gym equipment was installed in urban parks in Southern California, and general environmental improvements were carried out [76]. The UK study was set in Durham in the North of England, and involved cleaning and repainting a bus station [77]. Both studies found significant improvements in at least some fear of crime outcomes (change scores not reported in one study [76]; a significant $8.1 \%$ improvement in perceived risk, but no significant change in feelings of safety (change scores not reported) in the other study [77]). 


\section{Population subgroups and inequalities}

Most information on the differential effect of interventions related to age and gender. Ethnicity was investigated in one study alone [72] and the effects of socioeconomic status, or relevant proxy measures, on outcomes were not investigated in any studies. Supplementary Additional file 3 discusses the findings and presents harvest plots for age, gender and ethnicity.

The findings on age were mixed, with some studies showing greater effect in older people and some showing greater effect in younger people. The findings on gender tended to show slightly greater improvements for women than for men. However, the only study to directly measure an interaction between intervention exposure and gender was the non-crime-focused intervention in Durham, which found consistently greater effectiveness for men than women across four outcomes; however, only in one outcome did the difference reach significance [77].

\section{Discussion and conclusions}

The findings of this review indicate that some environmental interventions may have the potential to reduce fear of crime, although in no case is the evidence conclusive. The most promising categories of intervention appear to be home security improvements (category 1), at least in certain contexts, and general environmental improvements, for which some limited evidence was found (category 7). In most other categories there was little evidence of reducing fear of crime. Where positive findings emerged from non-comparative studies, they were rarely confirmed by more robust designs with matched comparison groups. In some cases, such as street lighting (category 2), effect sizes found in controlled studies were lower than in uncontrolled studies.

Installation of CCTV (category 3) appeared to be the least promising of the interventions, with consistent evidence of ineffectiveness in reducing fear of crime; however, it is possible that these findings may be confounded if CCTV was installed in areas known to be crime 'hot spots'.

Findings in the other four categories were more equivocal, with some positive findings, though none provide strong evidence of reductions in fear of crime. Of concern is the finding from one study of increased fear of crime [67]. This was a large housing improvement program in Glasgow, Scotland; the study authors speculate that relocation may have had disruptive effects on social networks, hence increasing fear of crime. This hypothesis remains to be tested.

In general, the evidence base covered in the review has considerable limitations. Study quality is generally poor, with very few studies using robust designs with adequately matched control groups, and many studies not conducting appropriate statistical analyses. For those categories containing few rigorously conducted studies, CCTV and multi-component environmental programs in particular, the results should be regarded as indicative only.

One of the most serious limitations of the evidence base is the heterogeneity in the outcome measures aggregated as 'fear of crime' in this review. This heterogeneity, and the associated problems with the concept of fear of crime itself, have been subject to sustained critique. The different definitions of fear have been shown to lead to widely varying empirical results and arguably do not access the same underlying construct [78-81]. Supplementary Additional file 4 shows the different types of fear of crime outcome measures included in the studies; as shown, there is wide variation in the types of outcome included. While we have simply aggregated these distinct outcomes in this review as though they referred to the same construct, it should be borne in mind that the heterogeneity of measures places limitations on what can be inferred from the results. In particular, several of the studies with the most positive trends only measured perceived safety, rather than affective fear; $[50,61,76,77]$ such outcomes could be hypothesized to have a lesser impact on wellbeing.

Positive mental health is increasingly recognized as an important aspect of public health and may be influenced by good living environments, housing, employment, transport, education and a supportive political structure; and at a community level, by a sense of belonging, social support, a sense of citizenship and participation in society [82]. Fear of crime is one important mechanism (or pathway) which mediates the relationship between these influences and mental health and wellbeing. This review has found some support for the role of physical environment as a target for effective interventions, although further evaluative evidence is needed. As both crime and mental health and wellbeing are strongly socially patterned, future research should also have a clearer equity focus particularly taking account of socioeconomic status, ethnicity and gender.

\section{Endnotes}

a The Pennsylvania, PA, USA, study [47] was conceived as a controlled design, but is treated in this review as uncontrolled because the comparison group appear to have benefited from the intervention as much as the 'intervention' group.

b The Petticrew et al. study in Scotland [70] used a controlled design, but only within-group findings are available for fear outcomes. 


\section{Additional files}

\section{Additional file 1: MEDLINE search strategy. \\ Additional file 2: Quality assessment for the systematic review of effectiveness. \\ Additional file 3: Findings on population subgroups. \\ Additional file 4: Fear of crime outcome measures.}

\section{Abbreviations}

ASSIA: Applied Social Sciences Index and Abstracts; CCTV: closed-circuit television; CINAHL: Cumulative Index to Nursing and Allied Health Literature; CPTED: crime prevention through environmental design; ERIC: Education Resources Information Center; HMIC: Health Management Information Consortium; NCJRS: National Criminal Justice Reference Service; NDC: New Deal for Communities; NIHR: National Institute for Health Research; OECD: Organization for Economic Co-operation and Development; PHR: Public Health Research; PRISMA: Preferred Reporting Items for Systematic Reviews and Meta-Analyses; RCT: randomized controlled trial; SRB: Single Regeneration Budget.

\section{Competing interests}

The authors declare that they have no competing interests.

\section{Authors' contributions}

The idea for the study was formulated by MP and MW, with input from HT, SCu, AS and AR. Searches were conducted by KW. Screening and coding were conducted by TL, DN and SCl. TL conducted the data analysis and wrote the first draft of the manuscript. All authors contributed to revising the manuscript and approved the final draft.

\section{Acknowledgements}

This project was funded by the National Institute for Health Research Public Health Research (NIHR PHR) Programme (project number 09/3000/14). The views expressed are those of the authors and do not necessarily reflect those of the NIHR. We would like to thank the members of the project Advisory Group: Allan Brimicombe, John Middleton, David Nossiter, James Thomas, Rachel Tuffin and Sandra Walklate.

\section{Author details}

${ }^{1}$ Department of Social and Environmental Health Research, London School of Hygiene \& Tropical Medicine, 5-17 Tavistock Place, London WC1H 9SH, UK. ${ }^{2}$ Department of Public Health and Policy, University of Liverpool, PO Box 147, Liverpool L69 3GB, UK. ${ }^{3}$ Centre for Reviews and Dissemination, University of York, York YO10 5DD, UK. ${ }^{4}$ Social and Public Health Sciences Unit, 4 Lilybank Gardens, Glasgow G12 8RZ, UK. ${ }^{5}$ (formerly) School of Geography, Queen Mary, University of London, Mile End Road, London E1 4NS, UK. ${ }^{6}$ Institute for Health and Human Development, University of East London, Water Lane, London E15 4LZ, UK

Received: 7 December 2012 Accepted: 4 April 2013

Published: 12 May 2013

\section{References}

1. Lorenc T, Clayton S, Neary D, Whitehead M, Petticrew M, Thomson H, Cummins S, Sowden A, Renton A: Crime, fear of crime, environment, and mental health and wellbeing: mapping review of theories and causal pathways. Health Place 2012, 18:757-765.

2. Jackson J, Stafford M: Public health and fear of crime: a prospective cohort study. Br J Criminol 2009, 49:832-847.

3. Stafford M, Chandola T, Marmot M: Association between fear of crime and mental health and physical functioning. Am J Public Health 2007, 97:2076-2081

4. Tseng M, Yeatts K, Millikan R, Newman B: Area-level characteristics and smoking in women. Am J Public Health 2001, 91:1847-1850.

5. Robinson MB: The theoretical development of CPTED: 25 years of responses to C. Ray Jeffery. In Advances in Criminological Theory, Volume 8. Edited by Laufer W, Adler F. New Brunswick NJ: Transaction Publishers; 1999:427-462
6. Taylor R: Crime Prevention through Environmental Design (CPTED): Yes, no, maybe, unknowable, and all of the above. In Handbook of Environmental Psychology. New York: Wiley; 2002:413-426.

7. Welsh B, Farrington D: Effects of improved street lighting on crime. Campbell Syst Rev 2008, 13

8. Casteel C, Peek-Asa C: Effectiveness of crime prevention through environmental design (CPTED) in reducing robberies. Am J Prev Med 2000, 18:99-115.

9. Dannenberg AL, Jackson RJ, Frumkin H, Schieber RA, Pratt M, Kochtitzky C, Tilson $\mathrm{HH}$ : The impact of community design and land-use choices on public health: a scientific research agenda. Am J Public Health 2003, 93:1500-1508

10. Marmot M, Friel S, Bell R, Houweling TAJ, Taylor S: Closing the gap in a generation: health equity through action on the social determinants of health. Lancet 2008, 372:1661-1669.

11. Perry I: Violence: a public health perspective. Global Crime 2009, 10:368-395

12. National Collaborating Centre for Methods and Tools: Quality Assessment Tool for Quantitative Studies. Hamilton, ON: McMaster University; 2008. updated 13 April, 2010

13. Thomson H, Thomas S, Sellstrom E, Petticrew M: The health impacts of housing improvement: a systematic review of intervention studies from 1887 to 2007. Am J Public Health 2009, 99:S681-S692.

14. Allatt $P$ : Fear of crime: the effect of improved residential security on a difficult to let estate. Howard J Criminal Justice 1984, 23:170-182.

15. Allatt P: Residential security: containment and displacement of burglary. Howard J Criminal Justice 1984, 23:99-116.

16. Brownsell S, Blackburn S, Hawley MS: An evaluation of second and third generation telecare services in older people's housing. J Telemed Telecare 2008, 14:8-12.

17. Halpern D: Mental Health and the Built Environment: More than bricks and mortar?. Abingdon: Taylor \& Francis; 1995.

18. Matthews R, Trickey J: Eyres Monsell Crime Reduction Project. Leicester: University of Leicester; 1994.

19. Matthews R, Trickey J: New Parks Crime Reduction Project. Leicester: University of Leicester; 1994.

20. Atkins S, Husain S, Storey A: The Influence of Street Lighting on Crime and Fear of Crime. London: Home Office; 1991.

21. Bainbridge DI, Painter K: The Influence of Improvements to Public Lighting on Crime, Fear of Crime and Quality of Life: A study in the Moseley and Showell Green areas of Birmingham. Birmingham: Aston University; 1993.

22. Barr R, Lawes H: Towards a Brighter Monsall: Street lighting as a factor in community safety: The Manchester experience. Manchester: University of Manchester; 1991

23. Burden T, Murphy L: Street Lighting, Community Safety and the Local Environment: Summary of the Leeds project. Leeds: Leeds Metropolitan University; 1991

24. Davidson N, Goodey J: Street Lighting and Crime: The Hull Project. Hull: University of Hull; 1991.

25. Herbert D, Moore L: Street Lighting and Crime: The Cardiff Project. Swansea: University of Swansea; 1991.

26. Herbert D, Davidson N: Modifying the built environment: the impact of improved street lighting. Geoforum 1994, 25:339-350.

27. Knight C: Field surveys of the effect of lamp spectrum on the perception of safety and comfort at night. Light Res Technol 2010, 42:313-329.

28. Painter K: Lighting and Crime Prevention: The Edmonton project. London: Middlesex Polytechnic; 1988.

29. Painter $K$ : The influence of street lighting improvements on crime, fear and pedestrian street use, after dark. Landsc Urban Plan 1996, 35:193-201.

30. Painter K: Lighting, Crime Prevention and Community Safety: The Tower Hamlets project. First report. London: Middlesex Polytechnic; 1989.

31. Painter K: Evaluation of Public Lighting as a Crime Prevention Strategy with Special Focus on Women and Elderly People. Manchester: University of Manchester; 1991.

32. Painter K, Farrington DP: The crime reducing effect of improved street lighting: the Dudley project. In Situational Crime Prevention: Successful Case Studies. Edited by Clarke RV. Guilderland, NY: Harrow and Heston; 1997:209-226.

33. Painter K, Farrington DP: Street lighting and crime: diffusion of benefits in the Stoke-on-Trent project. Crime Prev Stud 1999, 10:77-122.

34. Painter K, Farrington DP: Evaluating situational crime prevention using a young people's survey. Br J Criminol 2001, 41:266-284. 
35. Payne S, Gardiner D: Street Lighting Improvements and the Fear of Crime in Rugby. Warwick: Warwickshire County Council; 2003.

36. Vamplew C: The Effect of Improved Street Lighting on the Perceptions of Crime: A before-and-after study. Middlesbrough: Cleveland County Council; 1990.

37. Vrij A, Winkel FW: Characteristics of the built environment and fear of crime: a research note on interventions in unsafe locations. Deviant Behav 1991, 12:203-215.

38. Brown B: CCTV (Closed Circuit Television) in Town Centres: Three Case Studies. London: Home Office Police Department; 1995.

39. Ditton J: Crime and the city: public attitudes towards open-street CCTV in Glasgow. Br J Criminol 2000, 40:692-709.

40. Gill M, Spriggs A: Assessing the Impact of CCTV: Home Office Research Study. London: Home Office; 2005.

41. Gill M, Bryan J, Allen J: Public perceptions of CCTV in residential areas: "It is not as good as we thought it would be". Int Crim Justice Rev 2007, 17:304-324.

42. Musheno MC, Levine JP, Palumbo DJ: Television surveillance and crime prevention: evaluating an attempt to create defensible space in public housing. Soc Sci Q 1978, 58:647-656.

43. Squires P: Evaluation of the llford Town Centre CCTV system. Brighton: University of Brighton; 1998.

44. Squires P: Independent Evaluation of the Installation of CCTV cameras for Crime Prevention in the Whitehawk Estate, Brighton. Brighton: University of Brighton; 2003.

45. Arthur Young \& Company: Cabrini-Green High Impact Program: Second-year evaluation report. Chicago, IL: City of Chicago Department of Planning, City and Community Development; 1978.

46. Arthur Young \& Company: Relationships between the Location, Fear and other Characteristics of Crime: A Study for the Cabrini-Green High Impact Program. Chicago, IL: City of Chicago Department of Planning, City and Community Development; 1978.

47. Baker TE, Wolfer $\mathrm{L}$ : The crime triangle: alcohol, drug use, and vandalism. Police Pract Res 2003, 4:47-61.

48. Donnelly PG, Kimble CE: An evaluation of the effects of neighborhood mobilization on community problems. J Prev Interv Community 2006, 32:61-80.

49. Donnelly PG, Kimble CE: Community organizing, environmental change, and neighborhood crime. Crime Deling 1997, 43:493-511.

50. Felson $M$, Belanger ME, Bichler GM, Bruzinski CD, Campbell GS, Fried CL, Grofik KC, Mazur IS, O'Regan AB, Sweeney PJ, Ullman AL, Williams LM: Redesigning hell: preventing crime and disorder at the Port Authority Bus Terminal. In Preventing Mass Transit Crime. Edited by Clarke RV. Monsey, NY: Criminal Justice Press; 1996:5-92.

51. Fowler FJ, Mangione TW: Neighborhood Crime, Fear and Social Control: A second look at the Hartford Program. Washington, DC: National Institute of Justice; 1982.

52. Fowler FJ, McCalla ME, Mangione TW: Reducing Residential Crime and Fear: The Hartford neighborhood crime prevention program. Washington, DC: National Institute of Law Enforcement and Criminal Justice; 1979.

53. Fowler FJ, Mangione TW: A three-pronged effort to reduce crime and fear of crime: the Hartford experiment. In Community Crime Prevention: Does it Work? Edited by Rosenbaum DP. Beverly Hills, CA: Sage; 1986:87-108.

54. Hollander B, Hartmann FX, Brown RR, Wiles R: Reducing Residential Crime and Fear: The Hartford neighborhood crime prevention program. Washington, DC: National Institute of Law Enforcement and Criminal Justice; 1979.

55. Kaplan HM, Bickman L, Pesce EJ, Szoc R: Crime Prevention Through Environmental Design: Final report on schools demonstration, Broward County, Florida. Washington, DC: National Institute of Justice; 1978.

56. Kaplan HM, O'Kane KC, Lavrakas PJ, Pesce EJ: Crime Prevention Through Environmental Design: Final report on commercial demonstration, Portland, Oregon. Washington, DC: National Institute of Justice; 1978.

57. Kushmuk J, Whittemore SL: A Re-evaluation of Crime Prevention Through Environmental Design program in Portland, Oregon. Executive Summary. Washington, DC: National Institute of Justice; 1981

58. Lavrakas PJ, Kushmuk J: Evaluating crime prevention through environmental design: the Portland commercial demonstration project. In Community Crime Prevention: Does it Work? Edited by Rosenbaum DP. Beverly Hills, CA: Sage; 1986:202-227.

59. Mazerolle LG, Roehl J: Controlling Drugs and Social Disorder Using Civil Remedies: Final Report of a Randomized Field Experiment in Oakland, California. Washington, DC: National Institute of Justice; 1998.
60. Mazerolle LG, Kadleck C, Roehl J: Controlling drug and disorder problems: the role of place managers. Criminol 1998, 36:371-404.

61. Webb B, Laycock G: Reducing Crime on the London Underground: An Evaluation of Three Pilot Projects. London: Home Office; 1992.

62. Barnes R: Housing and Health Uncovered. London: Shepherds Bush Housing Association; 2003.

63. Blackman T, Harvey J, Lawrence M, Simon A: Neighbourhood renewal and health: evidence from a local case study. Health Place 2001, 7:93-103.

64. Blackman T, Harvey J: Housing renewal and mental health: a case study. J Ment Health 2001, 10:571-583.

65. Critchley R, Gilbertson J, Green G, Grimsley M: Housing Investment and Health in Liverpool. Sheffield: Sheffield Hallam University; 2004

66. Foster J, Hope T, Dowds L, Sutton M: Housing, Community and Crime: The impact of the Priority Estates Project. London: Home Office; 1993.

67. GoWell: GoWell: Synthesis of Research Findings 2006-2009. Glasgow: Glasgow Centre for Population Health; 2010.

68. GoWell: Progress for People and Places: Monitoring Change in Glasgow's Communities: Evidence from the GoWell Surveys 2006 and 2008. Glasgow: Glasgow Centre for Population Health; 2010.

69. Nair G, Ditton J, Phillips S: Environmental improvements and the fear of crime: the sad case of the "pond" area in Glasgow. Br J Criminol 1993, 33:555-561.

70. Petticrew M, Kearns A, Mason P, Hoy C: The SHARP study: a quantitative and qualitative evaluation of the short-term outcomes of housing and neighbourhood renewal. BMC Publ Health 2009, 9:415.

71. Kearns A, Petticrew M, Mason P, Whitley E: SHARP Survey Findings: Mental Health and Well-being Outcomes. Edinburgh: Scottish Government Social Research; 2008.

72. Beatty C, Grimsley M, Lawless P, Manning J, Wilson I: Fear of Crime in NDC Areas: How do Perceptions Relate to Reality? Sheffield: Centre for Regional Economic and Social Research, Sheffield Hallam University; 2005.

73. Beatty C, Foden M, Lawless P, Wilson I: An Overview of Cross-Sectional Change Data 2002-2008: Evidence from the New Deal for Communities Programme. London: Department for Communities and Local Government; 2009.

74. Beatty C, Foden M, Grimsley M, Lawless P, Wilson I: Four Years of Change? Understanding the Experiences of the 2002-2006 New Deal for Communities Panel. London: Department for Communities and Local Government; 2009.

75. Rhodes J, Tyler P, Brennan A: The Single Regeneration Budget: Final Evaluation. Cambridge: University of Cambridge; 2007.

76. Cohen DA, Golinelli D, Williamson S, Sehgal A, Marsh T, McKenzie TL: Effects of park improvements on park use and physical activity: policy and programming implications. Am J Prev Med 2009, 37:475-480.

77. Palmer EJ, Hollin CR, Caulfield LS: Surveying fear: crime, buses and new paint. Crime Prev Community Saf 2005, 7:47-58.

78. Ferraro KF, LaGrange R: The measurement of fear of crime. Sociol Inq 1987, 57:70-97.

79. Vanderveen G: Interpreting Fear, Crime, Risk and Unsafety. The Hague: Boom Juridische uitgevers; 2006.

80. Hale C: Fear of crime: a review of the literature. Int Rev Victimol 1996, 4:79-150.

81. Farrall S, Jackson J, Gray E: Social Order and the Fear of Crime in Contemporary Times. Oxford: Oxford University Press; 2009.

82. Jenkins $R$, Meltzer $H$, Jones PB, Brugha T, Bebbington P, Farrell M, Crepaz Keay D, Knapp M: Foresight Mental Capital and Wellbeing Project. Mental health: Future Challenges. London: The Government Office for Science; 2008.

doi:10.1186/2046-4053-2-30

Cite this article as: Lorenc et al:: Environmental interventions to reduce fear of crime: systematic review of effectiveness. Systematic Reviews 2013 2:30. 